\title{
Jatropha curcas L: A sustainable feedstock for the production of bioenergy and by products
}

\author{
Kamrun Nahar ${ }^{1, *}$, Sanwar Azam Sunny ${ }^{2}$ \\ ${ }^{1}$ Department of Environmental Science and Management, North South University, Bangladesh \\ ${ }^{2}$ Department of Mechanical Engineering, University of Kansas, Lawrence, KS, United States
}

\section{Email address:}

nahar@northsouth.edu (K. Nahar), sanwar@ku.edu (S. A. Sunny)

To cite this article:

Kamrun Nahar, Sanwar Azam Sunny. Jatropha Curcas L: A Sustainable Feedstock for the Production of Bioenergy and by Products. Journal of Energy and Natural Resources. Vol. 3, No. 4, 2014, pp. 51-57. doi: 10.11648/j.jenr.20140304.12

\begin{abstract}
Pot experimental studies were carried out in Dhaka, Bangladesh from April 2011 to May 2013, to produce sustainable biomass feedstock of Jatropha curcas $L$. The experiment also focused to evaluate the morphological, physiological and physiochemical parameters of Jatropha including biofuel and seed cake characteristics after fuel extraction. The leaves, petioles and seeds of the plants were collected from the earthen pot to determine the nutrient contents. The current study provides a reliable account of the endogenic concentrations of nutrients present in petiole and their content in leaves and seeds. Experimental results revealed that the morphological parameters responded better in mature plant compared to young plant but the physiological parameter showed variations at 2 growth stages. The different nutrient contents, including the crude protein in the petiole, were higher than the leaves in the young plants when compared to older plant, whereas the reverse was observed at two year old mature plants. The seed kernel contained more nutrients, especially Nitrogen (6.97\%) and Crude Protein (43.15\%), followed by seed cake and the husk. After maturity, the plant provided about 250 to $300 \mathrm{ml}$ of crude oil per plant and the characteristics of fuel responded better (Flush point $-252^{\circ} \mathrm{C}$, Ignition point $325.8^{\circ} \mathrm{C}$, Specific gravity of 0.9222 , Density 0.91992 , high Cetane (Ignition Quality) number of 58.7, Sulfur \% of 0.128 , Iodine (103.67 mg/g) and Saponification $(197.88 \mathrm{mg} / \mathrm{g}$ ) value in comparison to fossil fuel, with higher nutrients content in seed cake residue as byproduct obtained after extraction of oil, which could be used as an excellent organic fertilizer, with nutrients value, N: $3.6 \%$, $\mathrm{P}_{2} \mathrm{O}_{5}: 1.9 \%$ and $\mathrm{K}_{2} \mathrm{O}: 1.5 \%$. Also the oil contains high percentage of unsaturated fatty acid $(78.74 \%)$ resulting in characteristically low levels of free fatty acids, which improves storability. The crude oil without any modification could easily be used in lamp for illumination. The presence of unsaturated fatty acids (high iodine value) allows it to remain fluid at lower temperatures. The low sulfur content indicates less harmful sulfur dioxide $\left(\mathrm{SO}_{2}\right)$ exhaust emissions when the oil is used as a fuel.
\end{abstract}

Keywords: Jatropha Curcas, Biofuel, Nutrient Uptake, Seed Cake, Physiochemical Properties

\section{Introduction}

In the recent past, biofuel derived from plant species has been a major renewable source of bioenergy. The utilization of energy crops as a source of renewable fuels is a concept with great relevance to currant ecological and economic issues at both national and global scales. This non-conventional source of energy will help in removing in regional imbalance in energy use by making energy available in a decentralized manner. The production of biofuel will lower national dependence on foreign oil supplies and will reduce emissions of greenhouse gases. Scientists have identified some plants that bear seeds rich in non-edible vegetative oil. The natural oils when processed chemically show striking similarities to petroleum derived diesel and are called biofuel. Global awareness of the climate changes tagged with gradual increase in Carbon di oxide emission in the atmosphere is creating a relative impact on society of the developed and developing countries.

Bioenergy, which is sometimes made from energy crops, is mainly a liquid or gas derived from biomass of organic plant material, second generation biofuel crops. These crops are not typically used for food purposes but can help supply a portion of the current fuel demand sustainably with minimum environmental impact (Jepsen et al., 2006). The biomass can 
be converted to fuel and used for various transportation and household purposes. These agro-based fuels are considered an important means of reducing greenhouse gas emissions and increasing energy security by providing an alternative to conventional petroleum based fossil fuel. In recent years, Bangladesh has been suffering from severe energy crisis in urban as well as in rural communities, as a result of its high population growth. Concerns regarding energy security, dependence on foreign resources, and the negative consequences associated with global warming due to continued greenhouse gas emissions have prompted significant interest in the development of low carbon and sustainable energy sources. Biofuels from nonfood bioenergy feedstock, like Jatropha curcas, is one such example, which is a second generation energy crop, propagated from seeds, to produce bioenergy and other byproducts for consumption in the context of the developing nation.

Biofuel is a tremendous opportunity to lead the nation to a brighter and better future with respect to energy and can offer environmental benefits such as lower carbon emissions and lower sulfur compared with conventional petroleum-based fuels (Nahar et al., 2011).

Global climate change has a direct effect on agriculture, the primary livelihood of the people of Bangladesh. In Bangladesh especially, water deficiency is a common phenomenon during summer and winter periods. If there were adequate supply of uncontaminated water during these periods, most food crop productions could be ensured. Winter is practically the safest period for crop production as there is little chance of crop failure due to climatic reasons, but the crops suffer from drought during this period. So there is a significant hamper of the growth of agriculture which needs to feed in excess of 162 million people within an area of 147,570 square kilometers, of which a minority is arable land. Further shrinkage is occurring due to erosion, deforestation and other man-made environmental effects. Agricultural production could be enhanced either by supplying adequate water to the crops or by growing drought resistant Plants. This could be done by selecting crops that have less demand for water or have deep root systems sufficient to utilize subsurface water.

They can replace fossil fuels in developed as well as in developing countries like Bangladesh while bringing additional income to poor farmers. As it is an easy to propagate drought resistant plant it can be cultivated on wastelands, without competing with current food production (Heller, 1996; Grimm, 1996). This plant can grow anywhere including soil considered infertile for food production, and can live for about 50 years (Henning, 2010; Openshaw 2000).

Recently, the plant is gaining a lot of importance for the production of biofuel (Biodiesel) in developed as well as in developing countries. The plant can be grown in low to high rainfall areas, light frost areas (short duration) and can be used to reclaim land, as a hedge and/or as a commercial crop. In addition, it can be grown in dry land areas and as well as in flooded lands, in shallow fields, rocky terrains and marginal and boundary lands. Completely inedible by both humans and animals, it is also an excellent bordering plant, hence prevents animals from wondering into and destroying valuable crops. It can be easily grown from stem cutting, grafting, tissue culture and seeds, and grow extremely fast, producing fruits for about many years. If planted along riverbanks and coastlines, it can prevent erosion and its leaves also enrich the surrounding soil (Nahar et al., 2011). The plant produces seeds containing inedible oil, which is easily convertible into biodiesel. Biodiesel is an alternative and renewable fuel derived from natural oil like jatropha oil. Originally from Central America, Jatropha is found throughout the tropics, including much of Africa and Asia (Openshaw 2000; Gubitz et al 1999). Different parts of Jatropha have medicinal values. Each and every part of the plant from roots to the leaves can be used for various purposes.

The plant thrives on different soil types including gravelly, sandy and also under saline conditions (Dagar, 2006). Seed production ranges from about 0.1 tons per hectare per year $(\mathrm{t} / \mathrm{ha} /$ year) to over $14 \mathrm{t} / \mathrm{ha} /$ year, (Heller, 1996; Becker, 2010; Openshaw, 2000; Achten et al., 2008; Jones \& Miller, 1991). The seeds contain about 30-35 percent of non-edible oil (Heller, 1996; Deng, 2010; Gubitz et al., 1999; Henning, 2002). One hectare of land, depending on density, can produce 158-396 gallons of oil (Chawla, 2010), as 0.26 gallon of oil can be extracted per 8.8 lbs (Achten, 2008) to $11-12$ lbs of seeds (Jongschaap, 2007). The plant is important for climate change issues as a mature plant or tree absorbs around $18 \mathrm{lbs}$ of carbon dioxide $\left(\mathrm{CO}_{2}\right)$ per year. So cultivating Jatropha in one hectare of land can sequester around 20 tons of $\mathrm{CO}_{2}$ annually (Benard Muok, 2008).

Additionally, the oil derived from the plant seeds directly can be used as a replacement for kerosene cooking fuel, to light lamps and also for energy in engines especially in small farming machineries in rural areas such as pumps for irrigation and machines for generators. The oil can also be converted into biodiesel for use in transportations and also as jet fuel (Cerrate et al 2006, Heller 1996, Achten et al. 2008). 1000 grams of Jatropha oil can produce 980 grams of pure biodiesel. However most optimized practical processes yield around 94\% of biodiesel (Alkabbashi et al., 2009), which emits $80 \%$ less $\mathrm{CO}_{2}$ and $100 \%$ less $\mathrm{SO}_{2}$ than fossil diesel (Tiwari et al., 2007). Besides the fuel, it produces many important byproducts after extraction of oil which can be used commercially (Jones \& Miller 1991, Nahar and Sunny 2011). Moreover, the important by-product is the seed cake or oil cake, is a good and balanced organic fertilizer containing, Nitrogen, Phosphorus and Potassium including other nutrients (Makkar et al, 2001; Ghosh et al. 2007; Patolia et al. 2007; Wani et al. 2006, Rockefeller Foundation, 1998), which the farmers can use in their fields. Besides that seedcake also contains a lot of energy that can be recovered by digesting it and producing biogas. Biogas digesters are currently a popular energy production unit in rural Bangladesh. In this 
way both the oil and pressed cake can be used to produce energy/electricity for a rural area which can lead to improved living conditions. Jatropha is considered as a sustainable source of second generation bioenergy feedstock species and the overall supply can be increased with different propagation technologies. In addition, the plant can grow in drought, and the land use patterns in Bangladesh are suitable for its cultivation (Nahar 2011). This can alleviate poverty to a degree and empower women in developing countries as traditionally the seeds have been harvested by women and used for medical treatments and local soap production (Duke 1983; Henning 2002).

So, for potential feedstock, focus has been made on the plant, where tremendous amount of research is being conducted on soil types, farming systems, breeding technologies, cultivation scenarios etc. As a fast growing, non-food energy source it does not require productive arable land that would otherwise be used for food crop production; does not require high amounts of pesticides, fertilizer and irrigation water, result in a lower carbon footprint in the total carbon life cycle basis and provide and equal or higher energy content than the current petroleum-based traditional fuel including jet fuel used by the industry and provides an environmental and socioeconomic benefit to local communities and countries.(OECD/FAO, 2007b).

The planting of Jatropha as a living hedge protects the soil from erosion. The roots of the tree bind the topsoil, so it is less vulnerable to the wind erosion-responsible for $28 \%$ of soil degradation (Becker and Francis, 2010). In addition to global climate changes and an excess of green-house gases, it addresses deforestation issues as it utilizes infertile, loamy and fallow lands production (Chawla, 2010).

The plant has enormous potential for energy production in Bangladesh. As a multipurpose plant with many attributes, it is considered as potential feedstock for biofuel production which could provide employment, improve the environment and may enhance the quality of rural life.

So, the aim of the present study was to investigate the growth, nutrient uptake and oil characteristics of an important oilseed bioenergy crop, taking in consideration the morphological and physiological quality of the underground and aboveground parts of the plant as well as fuel and seed cake characteristics in pot grown plant with limited soil in roof top condition.

\section{Materials and Methods}

The Pot experiment was conducted with Jatropha curcas, at author's roof top garden, Dhaka, Bangladesh. Seeds were obtained from local seed mass of Florida, USA. Homogenous seeds were soaked in wet paper towel for 24 hours before sowing and were sown on 1st April, 2011 in poly bags having size of $22 \times 12 \mathrm{~cm}$ and germinated on 7 th April. Poly bags were filled with mixed soil and well decomposed farm yard manure in equal proportion in ratio of $1: 1: 1$. The drainage holes were provided at the bottom of the polybags. 4 weeks seedlings were transplanted in $25 \mathrm{~cm}$ height and $30 \mathrm{~cm}$ diameter clay pots. The pots were filled with $8 \mathrm{kgs}$ of silty clay loam soil. The soil was collected from Tejgaon series, Bangladesh and the collected soil was air dried and sieved to pass a $2 \mathrm{~mm}$ mesh screen. The general physical and chemical characteristics of the soil were: Sand $5.8 \%$, Silt- $60.2 \%$, clay-34.0\%, Field capacity of the soil $33 \%$, Maximum water holding capacity- $46 \%$, Hygroscopic moisture-1.40\%, Porosity-49\%, Bulk Density-1.27g/cc, Particle Density - 2.57g/cc, PH 7.2, EC-143uS, OM - 1.14, CEC $-17.9 \mathrm{meq} / 100 \mathrm{~g}$ soil and $\mathrm{N}-0.06 \%$. The experiments were arranged to get all the plants in the pots with sufficient sunlight. Nutrient supply, water supply and other intercultural operations were done as and when necessary. Collection of petiole and leaves were done at 12 (1 year) months and 24 (2 years) months after transplanting. Other morphological data and physiological parameters at this two vegetative growth stages including the amount of oil, physiochemical properties of crude oil and nutrients value of kernel, seed husk and seed cake as a byproduct were also recorded. The samples were collected at the end of first year and 2nd year to measure the morphological and physiological parameters during the growing period. Finally at harvesting, sampled for growth (plant height, diameter, leaf and petiole length, fresh and dry wt, root length etc.) and also for the nutrients content. Plant heights were measured as the distance between soil surface and the main-stem apex. Leaf and petiole length were estimated non-destructively by measuring the distance from the point of petiole attachment to the leaf tip.

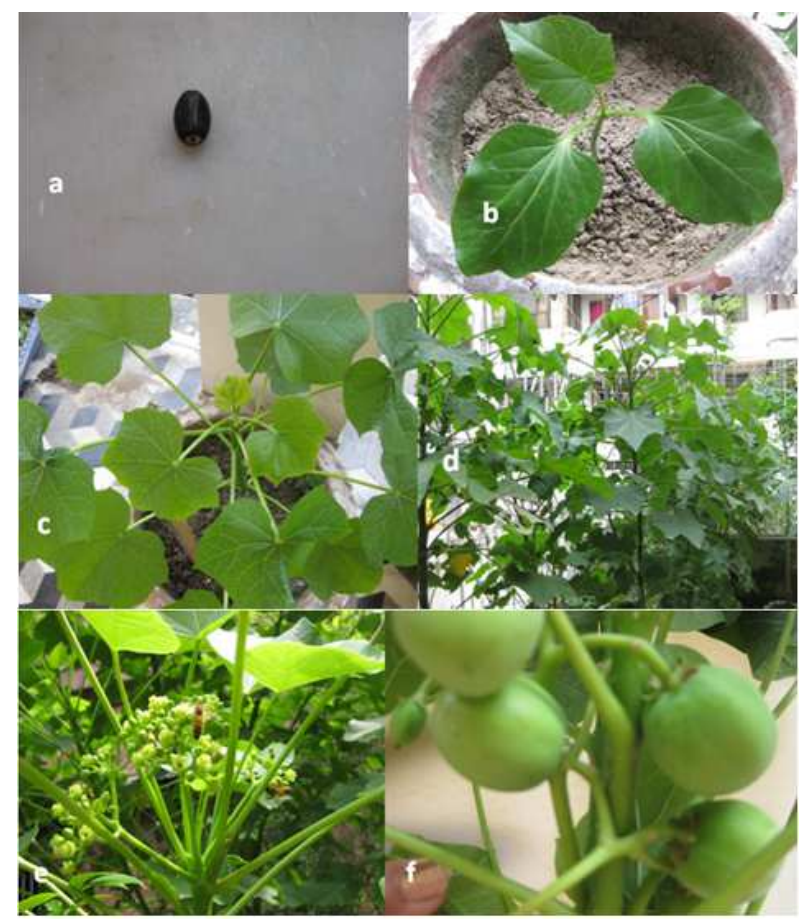

Figure 1. Different stages of plant growth. a-b. Seed to seedling, $c$-d. Plant at different growth stages, e-f. Multiple peduncles, Inflorescence initiation with blooming flowers and fruit formations (Flowering and fruiting after 2 years). 


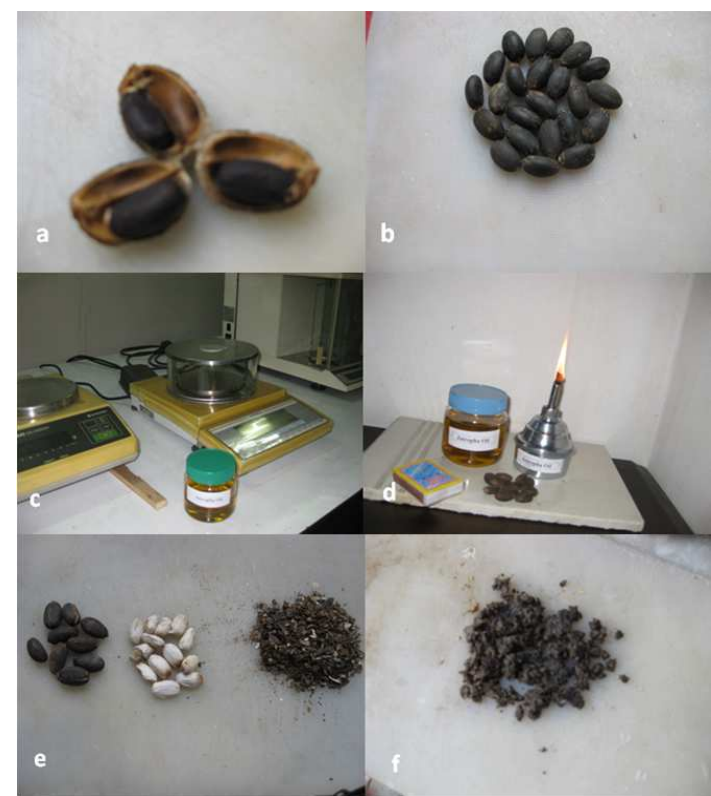

Figure 2. Seed to Seed Cake: a-b. Seeds with and without shell, $c$-d. Jatropha oil and burning lamp, e-f. Seed, kernel, husk and seed cake.

After harvesting, the samples were then dried for 48 hours at 47 degree Celsius to receive the dry wt of samples. The samples were than grind for chemical analysis and used for determination of nitrogen, crude protein and other nutrients content in plants. At maturity of the plant, the oil seeds were extracted and analyzed for their chemical and physical properties such as acid value, percentage free fatty acids ( $\%$
FFA), iodine value, saponification value as well as Specific gravity and density etc.

\section{Results and Discussion}

In the present study, the height and other morphological and physiological parameters of 1 and 2 years of the plants and seeds, oil properties were recorded. Results revealed that all the morphological parameter responded better in mature 2 years old plant compared to 1 year old plant (Table 1). But the physiological parameters like nutrient content showed variation at two growth stages. The percentage of Nitrogen and Sulfur were higher in 2 years old leaves but the concentration of potassium and phosphorus was lower compared to 1 year old leaves. But in case of petiole the percentage of all the nutrients were lower in mature plant except the Potassium content compared to young plant (Table 2-3).

The underground part, like root length increased with increasing age, which is a very important factor to consider in plant growth and development. The nutrient contents were found higher in the leaves than the petiole and increased with increasing age. These results also confirm the findings of Nahar and Hoque (2013), who observed better morphological response and nutrient contents in mature plant compare to young plant.

Table 1. Morphological parameters of 1 year and 2 years Jatropha plant.

\begin{tabular}{|c|c|c|c|c|c|c|c|c|c|c|}
\hline $\begin{array}{l}\text { Jatropha } \\
\text { Plant }\end{array}$ & $\begin{array}{l}\text { Plant height } \\
\text { (cm) }\end{array}$ & $\begin{array}{l}\text { Stem diameter } \\
(\mathrm{cm})\end{array}$ & $\begin{array}{l}\text { Leaf fresh } \\
\text { wt (gm) }\end{array}$ & $\begin{array}{l}\text { Petiole fresh } \\
\text { wt (gm) }\end{array}$ & $\begin{array}{l}\text { Leaf dry } \\
\text { wt (gm) }\end{array}$ & $\begin{array}{l}\text { Petiole dry } \\
\text { wt (gm) }\end{array}$ & $\begin{array}{l}\text { Leaf petiole } \\
\text { length }(\mathrm{cm})\end{array}$ & $\begin{array}{l}\text { Leaf length } \\
(\mathrm{cm})\end{array}$ & $\begin{array}{l}\text { Leaf width } \\
(\mathrm{cm})\end{array}$ & $\begin{array}{l}\text { Root } \\
\text { Length(cm) }\end{array}$ \\
\hline 1 year old & 35.47 & 1.68 & 2.68 & 1.52 & 0.58 & 0.016 & 14.88 & 13.56 & 12.44 & 18.39 \\
\hline 2 years old & 75.63 & 2.74 & 2.97 & 1.98 & 0.79 & 0.019 & 18.96 & 16.77 & 17.59 & 76.53 \\
\hline
\end{tabular}

Table 2. Physiological parameters of 1 year and 2 years Jatropha plant.

\begin{tabular}{llllll}
\hline Jatropha Plant & Plant height $(\mathbf{c m})$ & Stemdiameter $(\mathbf{c m})$ & Leaf fresh wt $(\mathbf{g m})$ & Petiole fresh wt $(\mathbf{g m})$ & Leaf dry wt $(\mathbf{g m})$ \\
\hline 1 year old & 35.47 & 1.68 & 2.68 & 1.52 & 0.58 \\
2 years old & 75.63 & 2.74 & 2.97 & 1.98 & 0.79 \\
\hline
\end{tabular}

Table 3. Physiological parameter of 2 year Jatropha plants.

\begin{tabular}{llllll}
\hline Samples & \% N & \% Crude protein & \% P & \% K & 0.38 \\
\hline Jatropha leaf & 1.96 & 11.89 & 0.19 & 0.19 & 0.99 \\
Jatropha Petiole & 0.84 & 4.73 & 0.09 & 0.14 & 0.9 \\
\hline
\end{tabular}

Table 4. Fatty acid composition (\%) of Jatropha seed oil.

\begin{tabular}{llllll}
\hline Unsaturated fatty acid & Saturated fatty acid & Oleic acid & Linoleic acid & Stearic acid & Palmitic acid \\
\hline $78.74 \%$ & $21.26 \%$ & $42.17 \%$ & $33.27 \%$ & $7.25 \%$ & $16.13 \%$ \\
\hline
\end{tabular}

At maturity, after 2 years, the plants provide seeds and each plant produces about $1 \mathrm{~kg}$ of seeds which produces about 250-300 $\mathrm{ml}$ of oil. When dried seeds are crushed, the resulting Jatropha oil produced can be used in lighting lamp, while the residue seed cake can be used as fertilizer. The composition of the seed shown in Table 5, with the important byproduct seed cake. 
Table 5. Jatropha Seed Kernel, Husk and Cake composition.

\begin{tabular}{|c|c|c|c|c|c|}
\hline Samples & $\% \mathbf{N}$ & \% Crude Protein & $\% \mathbf{P}$ & $\% \mathrm{~K}$ & $\% \mathrm{~S}$ \\
\hline Jatropha Seed Kernel & 6.97 & 43.15 & 0.994 & 0.98 & 1.20 \\
\hline Jatropha Seed Husk & 1.59 & 9.94 & 0.031 & 0.98 & 0.137 \\
\hline Jatropha Seed Cake & 3.60 & 22.5 & 1.92 & 1.53 & 1.12 \\
\hline
\end{tabular}

Table 6. Characteristics of Jatropha oil and comparison with fossil diesel.

\begin{tabular}{lll}
\hline Characteristic/variable & Jatropha Oil & Fossil Diesel \\
\hline Density g/cc at $20^{\circ} \mathrm{C}$ & 0.91992 & 0.8556 \\
Specific Gravity $20^{\circ} \mathrm{C}$ & 0.9222 & 0.852 \\
Iodine Value $\mathrm{mg} / \mathrm{g}$ & 103.67 & - \\
Flush Point ${ }^{\circ} \mathrm{C}$ & 252 & 87.6 \\
Ignition Point ${ }^{\circ} \mathrm{C}$ & 325.8 & 215 \\
Saponification value $\mathrm{mg} / \mathrm{g}$ & 197.88 & - \\
Cetane no. & 58.7 & 52 \\
Sulfur $\%$ & 0.128 & 1.22 \\
\hline
\end{tabular}

The energy gain from Jatropha does not only rely on the production of crude oil but also on the use for organic fertilizer with higher nutrients content in seed cake residue as byproduct obtained after extraction of oil, which could be used as an excellent organic fertilizer, with nutrients value, $\mathrm{N}$ : $3.6 \%, \mathrm{P}_{2} \mathrm{O}_{5}: 1.9 \%$ and $\mathrm{K}_{2} \mathrm{O}: 1.5 \%$. These results also confirm the findings of Achten (2008), Patolia (2007) and Wani (2006), who observed higher nutrient contents in the cake of Jatropha seed. The nutrients contained in the seed kernel, husk and seed cake are also shown in the Table 5. Seed husks can also be used as a feedstock for a gasification plant.

The property of different fats and oils depends upon characterization of the degree of unsaturation or saturation. Hence different oils are less or more saturated according as they contain greater or lesser proportion of the saturation in fatty acids. In this experiment, the various number of test parameters like: saponification value (SV), iodine value (IV), Cetane number $(\mathrm{CN})$ and other parameters had been estimated and the results are presented in Table 6 . The iodine value is a measure of the average amount of unsaturation of fats and oils. The oil shows a high iodine value due to its high content of unsaturated fatty acids (Table 6). Jatropha seed oil extracted from the plant has higher iodine as well as saponification value, which were $103.67 \mathrm{mg} / \mathrm{g}$ and 197.88 $\mathrm{mg} / \mathrm{g}$ respectively. This result also confirm the finding of Email et al., (2009), who observed higher Saponication, Iodine and acid values in the extracted oil.

The physiochemical properties of Jatropha oil were studied and compared with fossil diesel (Table 6). The specific gravity of diesel was 0.855 and it was also reduced to a significant extent when compared with the specific gravity of raw Jatropha oil (0.9222). The cetane index of oil was 58.7and it was found higher than the range of fossil diesel.

Fuel from Jatropha causes less air pollution during engine operation because it contains lower $\mathrm{S}$ concentration than petroleum diesel. Also due to higher density and specific gravity than the diesel, the fuel is safer to store than petroleum diesel since it has a higher flash point. These observations are also in agreements with Brittaine and Lutaladio (2010), who postulated the same findings on fuel characteristics of Jatropha oil.

Flash point (FP) and Ignition point (IP) are the important factors to consider in the handling, storage, and safety of fuels and flammable materials. In the current research, the flash point and ignition point determined and presented in Table 6 , (FP $252^{\circ} \mathrm{C}$, IP $325^{\circ} \mathrm{C}$ ), and was higher than the fossil diesel fuel. These results also confirm the findings of Singh and Padhi (2009), who also observed about the similar results.

According to Table 4, the free fatty acid content of raw Jatropha oil obtained from the research work was found to be nearly the same as described by Joshi et al (2011). The major long chain fatty acids present in the oil, which are palmitic acid $(16.13 \%)$, stearic acid $(7.25 \%)$, oleic acid $(42.17 \%)$ and linoleic acid (33.27\%). Based on the physicochemical evaluation of the oil obtained from the seeds, contains high percentage of unsaturated fatty acid which is about $78.74 \%$. The extracted oil can be classified as an unsaturated oil due to the presence of sufficient amounts of oleic and linoleic acids. Hence the oil has a great potential for various applications including low pour point biofuel. Therefore, it is necessary to have more research on Jatropha in the future to explore its potential for future industrial oilseeds crop. The presence of unsaturated fatty acids with high iodine value, allows it to remain fluid at lower temperatures. Also the low sulfur content in the oil (Table 6) indicates less harmful sulfur dioxide $\left(\mathrm{SO}_{2}\right)$ exhaust emissions when the oil is used as a fuel. These characteristics make the oil highly suitable for producing biodiesel and other byproducts.

\section{Conclusion}

Vegetative growth and other physiological parameter of Jatropha, based on the measurement and analysis of the above-ground part of the plant at two growth stages in the pots, concluded that 2 years old plant has higher growth, crude protein and nutrient concentrations compared to 1 year old plant as it is not well-developed. After extraction, seeds are providing oil and seedcake as organic fertilizer, could be used for industrial purposes. In conclusion mature plant 
shows better morphological parameters and sustainability. So sustainability is a main success factor for biofuel production. Since feedstock is the single largest cost component in biofuel production, considerably less expensive feedstock like Jatropha is the cheapest and the viable options. In the view of current energy crisis, this oil seems to be an attractive alternative source of energy, along with properties comparable to that of conventional diesel oil, so, we can consider the plant as a sustainable perennial bioenergy feedstock, provides a clean and renewable energy source where Environmental, social and economic matters have to be considered.

Soils of Bangladesh are suitable to cultivate the plant. The waste lands, and other upland, low land, lake/riverside can be easily taken consideration under Jatropha cultivation. Since the productivity remains variable over the globe, there is an urgent need for better and available data to guide investments and for that more research work is needed to provide for a sustainable future for Jatropha, which will lead to energy development in Bangladesh and elsewhere while saving the environment from conventional energy production.

\section{Acknowledgements}

The authors wish to thank Professor Tamim Ahmed for providing the necessary fuel analysis laboratory facilities at the Department of Petroleum and Mineral Resources Engineering, Bangladesh University of Science and Technology (BUET) and Dr. Sirajul Haque for plant, seed and soil sample analysis at the Laboratory of the Department of Soil, Water and Environment, University of Dhaka, Bangladesh.

\section{References}

[1] Achten, W.M.J., L. Verchot, Y.J. Franken, E. Mathijs, V.P. Singh, R. Aerts, and B. Muys. 2008. Jatropha bio-diesel production and use. Biomass and Bioenergy 32 (12):1063-1084

[2] Alkabbashi, A.N., M.Z. Alam, M.E.S. Mirghani and A.M.A.Al-Fusaiel. 2009. Biodiesel production from crude palm oil by transesterification process. J. Applied. Sci., 9:3166-3170.

[3] Joshi, A., P. singhal and R. K. Bachheti. 2011. Physicochemical Characterization of Seed oil of Jatropha curcas 1. collected from Dehradun (Uttarakhand) India. International Journal of Applied Biology and pharmaceutical technology. 2(2): 123-127.

[4] Becker, K. and G. Francis. 2010. Bio-diesel from Jatropha plantations on degraded land. Multifunctional Plants - Food, Feeds and Industrial Products Department of Aquaculture Systems and Animal Nutrition, University of Hohenheim.

[5] Brittaine, R., and N. Lutaladio. 2010. Jatropha: $A$ Smallholder Bioenergy Crop - The Potential for Pro-Poor Development.Rome, Italy: Food and Agriculture Organization of the United Nations. Accessed August 25, 2011. http://www.fao.org/docrep/012/i1219e/i1219e.pdf.
[6] Chawla P. C. 2010. CSIR NEWS: Progress, Promise and Prospects. 60 (7) - (8):74. ISSN 0409-7467.

[7] Cerrate, S., F. Yan, Z. Wang, C. Coto, P. Sacakli and P.W. Waldroup. 2006. Evaluation of glycerine from biodiesel production as a feed ingredient for broilers. Int. J. Poult. Sci., 5: 1001-1007.

[8] Deng, X., Z. Fang, Y. Liu. 2010. Ultrasonic transesterification of Jatropha curcas L. oil to biodiesel by a two-step process. Energy Conversion Management; 51: 2802-2807.

[9] Duke, J.A. 1983. Handbook of Energy Crops.Purdue University. Centre for New Crops and Plant Products. Unpublished.

[10] Dagar, J. C., O.S. Tomar, Y. Kumar, H. Bhagwan, R.K. Yadev and K. Tyagi. 2006. Performance of some under-explored crops under saline irrigation in a semiarid climate in Northwest India, Land Degrad. Develop. 17:285-299

[11] Email, A., Z. Yaakob., S.K.Kamarudin.,M. Ismail and J. Salimon. 2009. Characteristic and Composition of Jatropha Curcas Oil Seed from Malaysia and its Potential as Biodiesel Feedstock Feedstock. European Journal of Scientific Research. 29 (3):396-403. ISSN 1450-216X

[12] Grimm, C. 1996. The Jatropha project in Nicaragua.Bagani Tulu (Mali) 1: 10-14.

[13] Gubitz, G.M., M. Mittelbach, and M. Trabi. 1999. Exploitation of the tropical oil seed plant Jatropha curcas L. Bio res Technol 67:73-82.

[14] Ghosh, A., D. R. Chaudhary, M. P. Reddy, S. N. Rao, J.Chikara, and J. B. Pandya. 2007. "Prospects for JatrophaMethyl Ester (Biodiesel) in India.” Int. J Environ. Stud. 64:659-674.

[15] Heller, J. 1996. Physic nut. Jatropha curcas L. Promoting the conservation and use of underutilized and neglected crops. 1. Institute of Plant Genetics and Crop Plant Research, Gatersleben, International Plant Genetic Resources Institute, Rome.

[16] Henning, R. 2002. Using the Indigenous Knowledge of Jatropha - The use of Jatropha curcas oil as raw material and fuel .IK Notes. No.47. August. World Bank

[17] Henning, R. K. 2010. Jatropha curcas in Africa - an Evaluation.Assessment of the impact of the dissemination of "the Jatropha System" on the ecology of the rural area and the social and economic situation of the rural population (target group) in selected countries in Africa.

[18] IEA- International Energy Agency (2007b): Bioenergy Project Development and biomass supply. IEA good practice guidelines. OECD/IEA, Paris.

[19] Jones, N., J.H. Miller. 1991. Jatropha Curcas- A multipurpose species for problematic sites. Land resources series. 1:40-43.

[20] Jepsen, J.K., Henning, R.K. and Nyati, B. 2006. Generative propagation of Jatropha curcas L. on Kalahari Sand.Environment Africa. Zimbabwe.

[21] Jongschaap, R.E.E., W.J.Corre, P.S Bindraban and W.A. Brandenburg. 2007. Claim and Facts on Jatropha curcas L. Global Jatropha curcas evaluation, breeding and propagation programme. Plant Research International. Wageningenur. 
[22] Muok, B. 2008. Feasibility study of Jatropha curcas as a biofuel feedstock in Kenya. African Centre for Technology studies (ACTS).

[23] Makkar, H.P.S., Becker, K and B. Schmook. 2001. Edible provenances of Jatropha curcas from Quintna Roo state of Mexico and effect of roasting on antinutrient and toxic factors in seeds. Institute for Animal Production in the Tropics and Subtropics (480), University of Hohenheim, D-70593 Stuttgart, Germany.

[24] Nahar, K. 2011. Cultivation of Jatropha curcas L. in Bangladesh: A Sustainable Solution to the Energy, Environmental and Socioeconomic Crisis. VDM Publisher. ISBN 9783639365801.

[25] Nahar, K and S.A. Sunny.2011. Extraction of Biodiesel from a Second Generation Energy Crop (Jatropha curcas L.) by Transesterification Process. Journal of Environmental Science and Technology.4 (5): 498-503. DOI: 10.3923/jest.2011.498.503

[26] Nahar. K., S. A. Sunny and S. S. Shazi, 2011. Land Use requirement and urban growth Implications for the production of biofuel in Bangladesh. Canadian Journal on Scientific and Industrial Research. 2(6): 195-208.

[27] Nahar, K and Sirajul, H. 2013. A Morphological and Physiological Study of Jatropha curcas Linn.propagated from Seeds in Bangladesh. Middle-East Journal of Scientific Research $\quad 13 \quad$ (8): $1115-1118 . D O I$ : 10.5829/idosi.mejsr.2013.13.8.623
[28] Openshaw, K. 2000. A review of Jatropha curcas: An oil plant of unfulfilled promise. Biomass Bioenergy, 19: 1-15. Doi: 10.1016/s0961-9634(00)00019-2

[29] Rockefeller Foundation. 1998. The Potential of Jatropha curcas in Rural Development and Environment Protection An Exploration.Concept paper.Rockerfeller Foundation and Scientific \& Industrial Research \& Development Centre, Harare, Zimbabwe 1998.

[30] Singh, R. K and S.K. Padhi. 2009. Characterization of Jatropha oil for the preparation of biodiesel.Natural Product Radiance. 8(2): 127-132

[31] Tiwari, A. k., Kumar, A., Raheman, H. 2007. Biodiesel production from Jatropha oil (Jatropha curcas) with high free fatty acids: An optimized process. Biomass Bioenergy, 31(8): 569-575.

[32] Patolia, J. S., A. Ghosh., J. Chikara, D. R. Chaudharry, D.R. Parmar, and H. M. Bhuva. 2007. "Response of Jatropha curcas L. Grown on Wasteland to N and P Fertilization."

[33] Paper presented at the FACT Seminar on Jatropha curcas L. Agronomy and Genetics, March 26-28, Wageningen. Article No.34.

[34] Wani, S. P., M. Osman, E. D'Siva, and T. K. Sreedevi. 2006."Improved Livelihoods and Environmental Protection through Biodiesel Plantations in Asia." Asian Biotechnology and Development Review 8 (2): 11-29. 